\title{
Analisis Strategi Pemasaran Pada Toko Brunei Elektronik Meulaboh
}

Ditengah Pandemi Covid-19

\author{
Maulidar \\ Sekolah Tinggi Ilmu Administrasi Pelita Nusantara \\ maulidar@stiapen.ac.id
}

\begin{abstract}
This study aims to analyze the sales strategy applied to the Brunei Eletronik store amidst the weakening condition of the Indonesian economy due to the covid-19 pandemic. The method in this study was carried out with a qualitative approach to analyze the marketing strategy applied by the Brunei Eletronik store with primary data sources obtained from data collection techniques through interviews, observations and literature studies. From the results of the research carried out, it is known that a number of new facts related to the strategy implemented by the Brunei Eletronik store during the Covid-19 pandemic, sales decreased at the beginning of the outbreak of the Covid-19 pandemic in Indonesia, especially the West Aceh region due to reduced community activities outside the home, but with the use of technology in business strategies to increase sales, income gradually improves and increases. From the results of data analysis and literature review, to improve marketing strategies, Brunei Eletronik stores can apply the SWOT analysis method in increasing sales in the midst of the COVID-19 pandemic.
\end{abstract}

Keywords: Covid-19; Analysis; Strategy; Technology

\begin{abstract}
ABSTRAK
Penelitian ini bertujuan untuk menganalisis strategi penjualan yang diterapakn pada Toko Brunei Eletronik ditengah kondisi melemahnya ekonomi Indonesia akibat pandemic covid-19. Metode pada penelitian ini dilakukan dengan pendekatan kualitatif untuk mengalisis strategi pemasaran yang diterapkan oleh Toko Brunei Eletronik dengan sumber data primer yang diperoleh dari Teknik pengambilan data melalui wawancara, observasi dan kajian Pustaka. Dari hasil penelitian yang dilakukan maka diketahui sejumlah fakta baru terkait strategi yang diterapkan oleh Toko Brunei Eletronik selama pandemic covid-19 penjualan mengalami dampak penurunan di awal merebaknya pandemic covid-19 di Indonesia khusunya wilayah aceh barat karena berkurangnya aktifitas masyarakat diluar rumah, akan tetapi dengan pemanfaatan teknologi dalam strategi bisnis untuk meningkatkan penjualan maka pendapatan berangsur membaik dan meningkat. Dari hasil analisis data serta kajian literatur yang dilakukan maka untuk meningkatkan strategi pemasaran maka Toko Brunei Eletronik dapat menerapkan metode analisis SWOT dalam meningkatkan penjualannya ditengah pandemic covid-19.
\end{abstract}

\section{Kata kunci: Covid-19; Analisis; Strategi; Teknologi}




\section{PENDAHULUAN}

Brunei Elektronik merupakan salah satu toko elektronik terbesar yang ada di kota Meulaboh, Kabupaten Aceh Barat yang letaknya sangat strategis di pusat kota meulaboh. Dengan menempati lokasi yang startegis maka sangat memudahkan konsumen dalam menjangkau oleh masyarakat yang pada umumnya datang dari dua kabupaten tetangga yaitu Aceh Jaya dan Nagan Raya selain masyarakat dari kota Meulaboh sendiri. Produk barang elektronik yang ditawarkan juga sangat bervariasi sesuai selera konsumen antara lain, TV, Kulkas, mesin cuci dan AC. Ditengah pandemi covid-19 toko brunei elektronik harus memiliki strategi yang tepat dalam mempertahankan penjualan produknya sehingga bertahan ditengah terpuruknya ekonomi yang ada di Indonesia. Dampak virus corona juga memiliki pengaruh pada perilaku masyarakat terutama para konsumen toko brunei elektronik, perubahan perilaku pada masyarakat tersebut bisa berupa dalam pencarian informasi produk atau pembelian barang yang tidak lagi dilaklukan secara langsung melainkan membutuhkan banyak inovasi serta kemudahan bagi konsumen dalam memperoleh barang yang dibutuhkan tanpa harus menuju tempat barang yang akan dibeli. perubahan perilaku konsumen ini sangat berdampak pada daya beli bagi perusahaan yang memiliki inovasi dan strategi akan mampu mempertahankan hingga meningkatkan daya beli masyarakat walau ditengah masa pandemi covid-19 (Suliyanthini et al., 2021; Wardana dan Darma, 2020; Umami dan Darma, 2021; Dewi dan Darma, 2019; Darma dan Noviana, 2020; Murti dan Darma, 2021; Ferdiana dan Darma, 2019).

Merebaknya virus covid-19 pada awal tahun 2020 di indonesia menyita banyak perhatian masyarakat, terutama terkait ekonomi indonesia yang tidak stabil. banyak sektor berdampak langsung akibat pandemi covid-19 terutama pada sektor pasar yang paling rentan, peningkatan kasus yang semakin cepat semakin memperburuk keadaan terlebih dilakukannya PSBB pada peraturan pemerintah No 21 Tahun 2020, hingga saat ini diberlakukan PPKM ditahun 2021 membuat ruang aktifitas masyarakat terbatas terlebih sektor pasar yang dibatasi jumlah pengunjung dan waktu untuk membuka toko dan tidak hanya itu banyak perkantoran juga sampai harus tutup untuk sementara waktu (Zulkipli \& Muharir, 2021; Wulandari dan Darma, 2020; Priskila dan Darma, 2020; Shavitri dan Darma, 2020; Sudiwedani dan Darma, 2020; Handayani dan Darma, 2021; Rivaldo et al., 2021; Yong dan Darma, 2020; Darma et al., 2019).

Salah satu metode yang bisa diterapkan dalam menjaga dan meningkatkan strategi pemasaran di toko brunei darusalam adalah dengan menggunakan metode SWOT. Analisis SWOT merupakan metode yang dapat digunakan untuk menemukan strategi yang tepat 
dalam pengambilan sebuah keputusan bagi pelaku bisnis dengan proses analisis masalah yang mendalam serta tahapan pada analisis SWOT dilakukan secara sistematis. Hasil analisis SWOT dapat diterapakan pada pada instansi pemerintah dan juga perusahan, guna memaksimalkan kinerja dan juga target yang sudah menjadi fokus utamanya (Nggini, 2019). Peneletian ini menganalisis faktor-faktor yang ada diruang lingkup pemasaran pada toko brunei dengan membobot, merating dan memberikan nilai untuk memperoleh kelompok kuadran sehingga dapat diambil sebuah keputusan yang tepat.

\section{Strategi}

Strategi adalah gabungan dari kata stratos dan ego yang didasari dari kata strategos pada bahasa yunani, strategi memiliki makna atau tujuan dalam pencapaian sebuah hasil. yang mana startegi merupakan langkah atau konsep dalam usaha pencapaian tujuan. strategi membutuhkan kemampuan serta keahlian dari seseorang dalam mengembangkan organisasi atau lingkungannya untuk mencapai apa yang diinginkan. selain dari itu strategi juga merupakan langkah atau sikap guna menyamakan reaksi dari keadaan lingkungan tertentu yang dapat dianggap penting, adapun dalam persamaan tindakan harus dilakukan secara prioritas tanpa mengabaikan aspek -aspek tertentu. Strategi dirumuskan sedemikian rupa sehingga jelas apa yang sedang dan akan dilaksanakan perusahaan demi mencapai tujuan yang ingin dicapai.(Budio, 2019; Darma, 2005) salah satu strategi untuk meningkatkan pendapatan bisnis yakni kualitas kinerja karyawan yang mana karyawan yang bekerja harus ramah, rapi dan sudah diberikan pelatihan kecakapan. dengan kualitas kinerja karyawan yang baik akan sangat berdampak kepada meningkatknya keuntungan perusahaan. (Hijrah et al., 2020; Kanten dan Darma, 2017; Wahyuni dan Darma, 2019; Darma, 2005; Darma, 2012; Hendhana dan Darma, 2017).

\section{Pemasaran}

Pemasaran adalah tahapan dari proses bisnis dalam menilai keberhasilan produk yang telah dilahirkan dengan pemikirian yang menyeluruh serta berinovasi, adapun hasil akhri dari proses tersebut diharapkan dapat berupa nilai tambah atau profit yang dapat menguntunkan bisnis dari sebuah perusahaan. dalam pemasaran dibutuhkan banyak pihak yang terlibat pada prosesnya pihak tersebut tergabung pada sebuah lembaga pemasaran yang mana dalam upaya pengembangan pemasaran dibutuhkan keterpaduan antar lembaga serta kegiatan yang dilakukan lembaga tersebut dalam proses pemasaran (Kusuma, 2017; Wandari dan Darma, 2021; Dharmayanti dan Darma, 2020; Wulandari dan Darma, 2020; Agung dan Darma, 2019; 
Permanasari dan Darma, 2013). Sedangkan pengertian Pasartransaksi yang dilakukan oleh penjual dengan pembeli pada suatu tempat dengan proses pertukaran barang atau jasa dengan uang atau benda yang bernilai guna memenuhi kebutuhan. Dalam perkembangannya pasar diklasifikasikan atas dua bentuk, yaitu pasar tradisional dan pasar modern. Pengertian pasar tradisional adalah yang dibangun dan dikelola oleh pemerintah, swasta, koperasi atau swadaya masyarakat setempat dengan tempat usaha berupa toko, kios, los dan tenda, atau nama lain sejenisnya, yang dimiliki/dikelola oleh pedagang kecil menengah, dengan skala usaha kecil dan modal kecil, dengan proses jual beli melalui tawar menawar (Aliyah, 2017; Kusnadi dan Darma, 2018; Handika dan Darma, 2018; Swari dan Darma, 2019; Maharani dan Darma, 2018; Darma, 2004; Arsriani dan Darma, 2013; Dewi dan Darma, 2018; Saefulloh dan Darma, 2014; Darma, 2005).

\section{SWOT}

Penerapan analisis SWOT pada bisnis dilakukan untuk mengetahui kekuatan, kelemahan, peluang serta anacaman bagi sebuah perusahaan agar dapat menyusun strategi yang sesuai. dengan mengetahui kekuatan yang dimiliki oleh sebuah perusahaan maka perusahaan akan punya kepercayaan diri dalam mengembangkan serta memajukan perusahaan. begitu juga halnya dengan kelemahan dengan analisis SWOT maka akan diperoleh strategi untuk menutupi kelamahan perusahaan sehingga tidak berdampak terhadap bisnis perusahaan. begitu juga halnya dengan peluang serta ancaman dari analisis SWOT, bagi perusahaan dapat menyiapkan startegi serta langkah - langkah agar terhindar dari kemungkinan terburuk untuk perusahaan (Tamara, 2016). Metode analisis SWOT merupakan analisis dengan mengenali faktor yang terstruktur dari kekuatan, kelemahan, peluang serta keuntungan dari sebuah perusahaan yang nantinya dapat dijadikan sebagai landasan untuk menentukan langkah serta strategi yang akan diterapkan pada sebuah perusahaan atau organisasi, tentu saja hal ini sangat berdampak positif bagi seluruh perusahaan dan dapat menjaga stabilitas perusahaan. (Istiqomah \& Andriyanto, 2018).

\section{METODE PENELITIAN}

Penelitian ini menerapkan metode analisis SWOT, pada analisis SWOT ada 4 kuadran yang terbagi berdasarkan gambar yang tampak pada gambar 1 


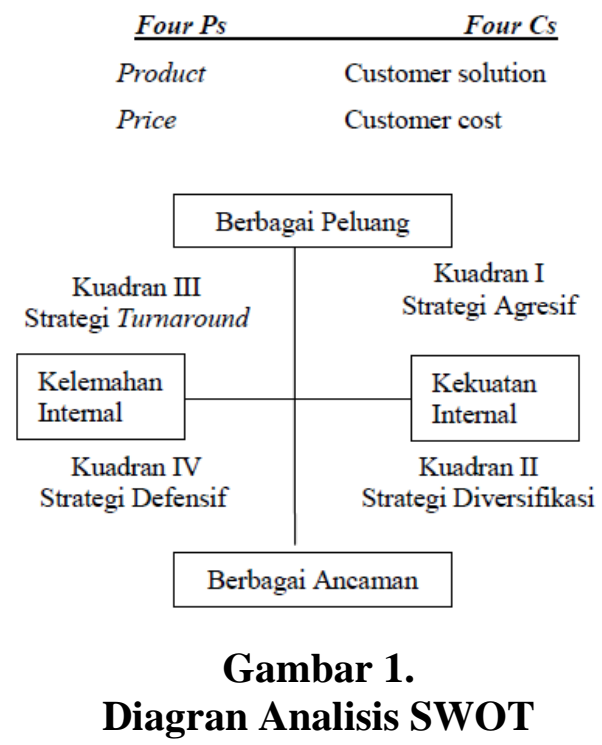

Kuadran 1 : Pada kuadran 1 perusahaan memperoleh peluang serta kekuatan yang lebih cepat, perusahaan yang berada di kuadran ini sangat diuntungkan karena pertumbuhan yang melesat

Kudran 2 : Perusahaan yang berada pada kuadran ini akan menghadapi banyak ancaman akan tetapi dengan kekuatan internal yang dimiliki akan mampu mendorong perusahaan untuk bertahan dengan memanfaatkan kekuatan yang dimiliki

Kuadran 3 : Pada kuadran ini perusahaan memiliki peluang yang disertakan kelamahan terutama di faktor internal, sehingga penguatan pada sektor internal lebih diutamakan untuk menjaga peluang

Kuadran 4 : Pada kuadran ke 4, perusahaan berada pada kondisi yang sulit karena banyak ancaman yang dihadapi oleh perusahaan serta kelemahan internal semakin memperburuk keadaan perusahaan.(Anwar \& Utami, 2012)

Analisis SWOT merupakan metode analisis yang setiap permasalahan akan dianalisis serta merujuk pada empat sisi, keempat sisi tersebut akan menawarkan solusi atau strategi yang dapat digunakan untuk menghindari kemungkinan terburuk yang akan terjadi analisis swot juga akan menguatkan strategi yang digunakan merujuk pada keempat sisi yang menawarkan strategi kekuatan internal.(Istiqomah \& Andriyanto, 2018) 


\section{HASIL DAN PEMBAHASAN}

Penerapan analisis SWOT yang dilakukan pada toko brunei elektronik menggunakan tabel matriks yang memiliki kolom pembobotan serta di beri penilaian dan total. dengan pemanfaatan tabel matriks akan diperoleh nilai yang sesuai dengan kelompok kuadaran yang memiliki strategi berbeda bedasarakan nilai total dari hasil perkalian bobot dan rating. Menurut David (2009) Tabel matriks yang digunakan pada analisis SWOT dapat membantu perusahaan dalam pengambilan keputusan dengan cara mengenali masalah serta faktor-faktor yang ada untuk dianalisis serta diperoleh nilai kuadran yang sesuai bagi perusahaan.(Annisa Mayang Indri Astuti, 2020). Berikut adalah tabel matriks analisis SWOT yang dilakukan toko elektronik brunei meulaboh untuk menentukan strategi atau kebijakan yang akan diambil ditengah pandemic covid-19

Tabel 1.

Analisis Pengaruh Internal

\begin{tabular}{|c|c|c|c|c|}
\hline \multicolumn{5}{|c|}{ I. Kekuatan } \\
\hline No. & Faktor & Bobot & Rating & Skor \\
\hline 1 & $\begin{array}{l}\text { Wilayah Meulaboh merupakan pusat kota yang menyediakan banyak } \\
\text { kebutuhan baik wilayah sendiri maupun wilayah kabupaten lain yang } \\
\text { berdekatan dengan Kabupaten Aceh Barat }\end{array}$ & 6 & 3 & 18 \\
\hline 2 & $\begin{array}{l}\text { Banyak konsumen diluar kabupaten yang membeli elektronik di wilayah } \\
\text { meulaboh }\end{array}$ & 8 & 3 & 24 \\
\hline 3 & Lokasi Toko yang startegis & 7 & 3 & 21 \\
\hline 4 & Tempat yang nyaman dan Luas & 6 & 2 & 12 \\
\hline 5 & Stock Produk Yang terdiri dari banyak Brand Ternama & 5 & 1 & 5 \\
\hline 6 & Pemanfaatan media sosial sebagai media promosi & 6 & 2 & 12 \\
\hline 7 & Dealer resmi dari produk-produk ternama & 6 & 1 & 6 \\
\hline 8 & Melayani pembelian besar seperti kantor & 6 & 2 & 12 \\
\hline \multicolumn{2}{|r|}{ Jumlah Skor Kekuatan } & 50 & & 110 \\
\hline \multicolumn{5}{|c|}{ II. Kelemahan } \\
\hline 1 & $\begin{array}{l}\text { Belum adanya ekspansi untuk membuka cabang yang menyebabkan jarak } \\
\text { konsumen ke toko yang jauh }\end{array}$ & 25 & -2 & -50 \\
\hline 2 & $\begin{array}{l}\text { Sistem manajemen internal yang tradisional membuat kebijakan terpusat } \\
\text { pada figure pemilik toko }\end{array}$ & 25 & -2 & -50 \\
\hline \multicolumn{2}{|r|}{ Jumlah Skor Kelemahan } & 50 & & -100 \\
\hline
\end{tabular}


Tabel 2.

Analisis Pengaruh Eksternal

\begin{tabular}{|c|c|c|c|c|}
\hline \multicolumn{5}{|c|}{ I. Peluang } \\
\hline No. & Faktor & Bobot & Rating & Skor \\
\hline 1 & $\begin{array}{l}\text { Banyaknya pembeli dari luar kabupaten sehingga meningkatkan jumlah } \\
\text { permintaan dan stock yang banyak }\end{array}$ & 17 & 3 & 51 \\
\hline 2 & $\begin{array}{l}\text { Harga yang terjangkau dan bersaing menjadikan toko ini sebagai standarisasi } \\
\text { harga jual barang }\end{array}$ & 15 & 2 & 30 \\
\hline 3 & $\begin{array}{l}\text { Pemanfaatan media sosial serta akun toko online semakin memudahkan } \\
\text { dalam mempromosikan toko }\end{array}$ & 18 & 2 & 36 \\
\hline \multicolumn{2}{|r|}{ Jumlah Skor Peluang } & 50 & & 117 \\
\hline \multicolumn{5}{|c|}{ II. Tantangan } \\
\hline No. & Faktor & Bobot & Rating & Skor \\
\hline 1 & $\begin{array}{l}\text { Pandemi covid-19 mengakibatkan daya beli masyarakat berkurang dan } \\
\text { ekonomi tidak menentu }\end{array}$ & 30 & 3 & 90 \\
\hline 2 & $\begin{array}{l}\text { Pembatasan kegiatan masyarakat karena penyebaran covid-19 mengakibatkan } \\
\text { terbatasnya aktifitas masyarakat }\end{array}$ & 20 & 3 & 60 \\
\hline \multicolumn{2}{|r|}{ Jumlah Skor Tantangan } & 50 & & 150 \\
\hline
\end{tabular}

Faktor internal pada faktor kekuatan terdapat 8 faktor yang menjadi kekuatan utama bagi toko elektornik brunei meulaboh, sedangkan faktor kelemahan hanya terdiri dari 2 faktor saja akan tetapi 2 faktor tersebut tersebut punya pengaruh yang besar dapat dilihat pada skor yang diperoleh oleh kedua faktor internal tersebut. Sedangkan faktor eksternal jumlah faktor yang mempengaruhi nya tidak jauh berbeda. Faktor peluang memiliki 3 faktor sedangkan tantangan ada 2 faktor akan tetapi pada faktor eksternal skor yang diperoleh sangat besar pada faktor tantangan. Besarnya pengaruhfaktor tersebut tidak terlepas karena kondisi pandemi yang ada saat ini.

\section{PENUTUP}

Berdasarkan hasil analisis yang dilakukan pada Toko Brunei Elektronik maka dapat disimpulkan posisi Toko Brunei Elektronik saat ini berada di kuadran II yang posisinya memiliki kekuatan akan tetapi sedang menghadapi tantangan yang besar salah satu tantangan yang dihadapi adalah ketidakpastian akan redanya penyebaran covid-19 khusunya di daerah meulaboh dan sekitarnya sehingga berdampak terhadap lemahnya daya beli masyarakat akan laju ekonomi yang melambat sehingga peneliti menyaranka agar Toko Brunei Elektronik melakukan diversifikasi strategi untuk segala kemungkinan tantangan yang akan datang 


\section{DAFTAR PUSTAKA}

Aliyah, I. (2017). Pemahaman Konseptual Pasar Tradisional di Perkotaan. Cakra Wisata, 18 (2): 16 .

Agung, N.F.A., and Darma, G.S. (2019). Opportunities and Challenges of Instagram Algorithm in Improving Competitive Advantage, International Journal of Innovative Science and Research Technology, 4 (1): 743-747.

Astuti, A.M.I., \& Shinta Ratnawati. (2020). Analisis SWOT Dalam Menentukan Strategi Pemasaran (Studi Kasus di Kantor Pos Kota Magelang 56100), Jurnal Ilmu Manajemen, 17 (2): 58-70.

Arsriani, I.A.I., and Darma, G.S. (2013). Peran Media Sosial Online Dan Komunitas Terhadap Keputusan Nasabah Bank, Jurnal Manajemen dan Bisnis, 10 (2): 48-68.

Anwar, M. C., \& Utami, M. C. (2012). Analisis SWOT pada Strategi Bisnis dalam Kompetisi Pasar (Studi Kasus: Toko Pojok Madura), Studia Informatika: Jurnal Sistem Informasi, 5 (1): 1-9.

Budio, S. (Sekolah T. A. I. Y. P. B. (2019). Oleh: Sesra Budio Sekolah Tinggi Agama Islam YAPTIP Pasaman Barat Abstrak Pengelolaan sekolah semakin penting dan menuntut perhatian yang sungguh-sungguh dari semua pihak yang terkait. Kurikulum, sarana prasarana, tenaga pengajar dan komponen lain bel. 2 (2): 56-72.

Darma, G.S., \& Noviana, I.P.T. (2020). Exploring Digital Marketing Strategies during the New Normal Era in Enhancing the Use of Digital Payment. Jurnal Mantik, 4 (3): 22572262. https://doi.org/10.35335/mantik.Vol4.2020.1084.pp2257-2262.

Darma, G.S., Wicaksono, K., Sanica, I.G., and Abiyasa, A.P. (2019). Faktor Kompensasi dan Strategi Gojek Dalam Meningkatkan Kepuasan Kerja Para Driver, JURNAL ILMIAH MANAJEMEN BISNIS DAN INOVASI UNIVERSITAS SAM RATULANGI, 6 (3): 232244.

Darma, G.S. (2012). 100 Konsultasi Praktis Strategi Bisnis. Denpasar: Undiknas Press.

Darma, G.S. (2005). Teknologi Informasi, Kepuasan User, Kinerja User dan Kinerja Hotel di Bali, Jurnal Ekonomi \& Bisnis, 17 (2): 93-102.

Darma, G.S. (2005). Konsultasi Praktis Marketing Strategy. Denpasar: Undiknas Press.

Darma, G.S. (2005). Managing Information to Greater Efficiency and Profit, Jurnal Ekonomi \& Bisnis, 17 (1): 1-10.

Darma, G.S. (2004). Improving the Aligment of Business and Information Strategies, Jurnal Ekonomi \& Bisnis, 16 (1): 1-28. 
Dharmayanti, P. D., \& Darma, G. S. (2020). The Use of Instagram in Coffee Shop. International Research Journal of Management, IT \& Social Sciences, 7 (4): 48-56. https://doi.org/10.21744/irjmis.v7n4.948

Dewi, M.V.K., and Darma, G.S. (2019). The Role of Marketing \& Competitive Intelligence In Industrial Revolution 4.0, Jurnal Manajemen \& Bisnis, 16 (1): 1-12.

Dewi, N.M.A.T., and Darma, G.S. (2016). Efektivitas Leadership, Growth Performance dan Regulasi Otoritas Jasa Keuangan, Jurnal Manajemen \& Bisnis, 13 (1): 1-13.

Ferdiana, A.M.K., and Darma, G.S. (2019). Understanding Fintech Through Go-Pay, International Journal of Innovative Science and Research Technology, 4 (2): 257-260. Handayani, L.P.D.S., \& Darma, G. S. (2021). Pengaruh Kebijakan Pemeriksaan, Kebijakan Akses Informasi Keuangan dan Forensik Digital terhadap Kualitas Pemeriksaan Pajak. Syntax Literate; Jurnal Ilmiah Indonesia, 6 (3): 1260-1272. http://dx.doi.org/10.36418/syntax-literate.v6i3.1142

Handika, M.R., and Darma, G.S. (2018). Strategi Pemasaran Bisnis Kuliner Menggunakan Influencer Melalui Media Sosial, Jurnal Manajemen \& Bisnis, 15 (2): 188-199.

Hendhana, S., and Darma, G.S. (2017). Service Quality Rumah Sakit dan Efeknya terhadap Patient Satisfaction, Perceived Value, Trust, dan Behavioral Intention, Jurnal Manajemen \& Bisnis, 14 (1): 37-55.

Hijrah., Mukhlizar, M., \& Pandria, T. M. A. (2020). Perbandingan Teknik Klasifikasi Untuk Memprediksi Kualitas Kinerja Karyawan, Jurnal Optimalisasi, 6 (1): 10-21. http://jurnal.utu.ac.id/joptimalisasi/article/view/1990.

Istiqomah, I., \& Andriyanto, I. (2018). Analisis SWOT dalam Pengembangan Bisnis (Studi pada Sentra Jenang di Desa Kaliputu Kudus), BISNIS : Jurnal Bisnis Dan Manajemen Islam, 5 (2): 363. https://doi.org/10.21043/bisnis.v5i2.3019.

Kanten, I.K., and Darma, G.S. (2017). Consumer Behaviour, Marketing Strategy, Customer Satisfaction, and Business Performance, Jurnal Manajemen \& Bisnis, 14 (2): 143165.

Kusuma, H. (2017). Analisis Pemasaran Jamur Merang Lembaga Mandiri Mengakar Masyarakat (LM3) Agrina Di Tanjong Paya Kecamatan Peusangan Kabupaten Bireuen, Journal of Chemical Information and Modeling, 53 (9): 1689-1699.

Kusnadi, D.S., and Darma, G.S. (2018). Menakar Implementasi Green Marketing Pada Usaha Kecil Menengah, Jurnal Manajemen \& Bisnis, 15 (1): 1-18.

Maharani, I.G.A.P.D., and Darma, G.S. (2018). Consumer Purchasing Behavior Analysis on Impulse Buying, Jurnal Manajemen \& Bisnis, 15 (3): 16-37. 
Murti, K.G.K., \& Darma, G. S. (2021). Jalan Terjal Online Travel Platform Hadapi Pandemi. Syntax Literate; Jurnal Ilmiah Indonesia, 6 (5): 2280-2296. http://dx.doi.org/10.36418/syntax-literate.v6i5.2703

Nggini, Y. H. (2019). Analisis SWOT (Strength, Weaknes, Opportunity, Threats) Terhadap Kebijakan Pengembangan Pariwisata Provinsi Bali, Jurnal Ilmiah Dinamika Sosial, 3 (1): 141. https://doi.org/10.38043/jids.v3i1.1739.

Permanasari, I.A.S., and Darma, G.S. (2013). Pengaruh Penggunaan Internet Banking Terhadap Rasa Aman, Rasa Percaya Dan Loyalitas Nasabah Dalam Meningkatkan Saldo Bank, Jurnal Manajemen dan Bisnis, 10 (1): 186-204.

Priskila, S., \& Darma, G.S. (2020). Employee Perception of Brand Value in the Jewelry Industry. Journal of Economics, Business, \& Accountancy Ventura, 23 (2). http://dx.doi.org/10.14414/jebav.v23i2.2281.

Rivaldo, I. M. G., Lestari, N.P.N.E., \& Darma, G.S., \& Gorda, A.A.N.E.S. (2021). Integrating The Credit Lending Strategies of Multi-Purpose Cooperatives (a Case Study at KSU Dauh Ayu in Denpasar), Jurnal Mantik, 4 (4): 2318-2324. https://doi.org/10.35335/mantik.Vol4.2021.1138.pp2318-2324

Saefulloh, D.A., and Darma, G.S. (2014). Strategi Marketing Wisata Wedding Sebagai Destinasi Alternatif, Jurnal Manajemen \& Bisnis, 11 (1): 17-34.

Shavitri, L.P.D., \& Darma, G.S. (2020). Pengaruh Implementasi Kebijakan Pemeriksaan dan Forensik Digital terhadap Kualitas Pemeriksaan dan Keberhasilan Penerimaan Pajak, E-Jurnal Akuntansi, 30 (10): 2682 - 2697.

https://doi.org/10.24843/EJA.2020.v30.i10.p19

Sudiwedani, A., \& Darma, G.S. (2020). Analysis of the effect of knowledge, attitude, and skill related to the preparation of doctors in facing industrial revolution 4.0, Bali Medical Journal, 9 (2): 524-530. https://dx.doi.org/10.15562/bmj.v9i2.1895.

Suliyanthini, D., Fashion, V., Education, D., Jakarta, U. N., Fashion, V., Education, D., \& Jakarta, U. N. (2021), Sosiologi, IX (April 2020): 18-24.

Swari, D.A.K.B.A., and Darma, G.S. (2019). Kepercayaan Lintas Generasi Dalam Penggunaan Social Media dan Electronic Word of Mouth, Jurnal Manajemen Bisnis, 16 (4): 145 161.

Tamara, A. (2016). Implementasi Analisis Swot Dalam Strategi Pemasaran Produk Mandiri Tabungan Bisnis, Jurnal Riset Bisnis Dan Manajemen, 4 (3): 395-406. 
Umami, Z., \& Darma, G. S. (2021). DIGITAL MARKETING: ENGAGING CONSUMERS WITH SMART DIGITAL MARKETING CONTENT, Jurnal Manajemen dan Kewirausahaan, 23 (2): 94-103. https://doi.org/10.9744/jmk.23.2.94-103

Wardana, I.M.A., \& Darma, G.S. (2020). Garment Industry Competitive Advantage Strategy During Covid-19 Pandemic, PalArch's Journal of Archaeology of Egypt / Egyptology, https://www.archives.palarch.nl/index.php/jae/article/view/2732.

Wahyuni, N.W.S., and Darma, G.S. (2019). Mobile Advertising, Product Social Value dan Purchase Intention pada Instagram, Jurnal Manajemen Bisnis, 16 (4): 87-101.

Wandari, N.K.M.A., \& Darma, G. S. (2021). Pengelolaan Karakter Green-Behavior Pada Generasi Milenial Dalam Meningkatkan Minat Penggunaan Green-Product, Jurnal Nusantara Aplikasi Manajemen Bisnis, 6 (1): 49-61.

https://doi.org/10.29407/nusamba.v6i1.14778

Wulandari, N.L.P.T., \& Darma, G.S. (2020). Textile Industry Issue in Pandemic of Covid-19, PalArch's Journal of Archaeology of Egypt / Egyptology, 17 (7): 8064-8074. Retrieved from https://archives.palarch.nl/index.php/jae/article/view/3526.

Wulandari, L.P.A., \& Darma, G.S. (2020). Advertising Effectiveness in Purchasing Decision on Instagram, Journal of Business on Hospitality and Tourism, 6 (2): 381-389. http://dx.doi.org/10.22334/jbhost.v6i2.220

Yong, I.D., \& Darma, G.S. (2020). Indikator Penentu Naik Turunnya Harga Saham pada Perusahaan High Deviden 20 Periode Tahun 2014-2019, Syntax Literate ; Jurnal Ilmiah Indonesia, 5 (12): 1591-1610. doi:10.36418/syntax-literate.v5i12.1907

Zulkipli., \& Muharir. (2021). menetapkan virus corona ini sebagai Kedaruratan Kesehatan Masyarakat yang Meresahkan Masyarakat (Public Health Emergency of International), JIMESHA: Jurnal Ilmiah Mahasiswa Ekonomi Syariah, 1 (1): 7-12. 